\title{
EVALUACIÓN DE ANTICUERPOS CONTRA EL VIRUS DE LA DIARREA VIRAL BOVINA DE UN HATO EN PROCESO DE ERRADICACIÓN DE LA ENFERMEDAD
}

\author{
Alfonso Zúñiga H. ${ }^{1}$, Hermelinda Rivera G. ${ }^{2,3}$, Mariluz Araínga R. ${ }^{1}$ y \\ Alberto Manchego S. ${ }^{2}$
}

\section{Abstract}

Antibodies against bovine viral diarrhea virus (BVDV) and antigen of BVDV were evaluated in serum samples from cattle aged 10 to 23 months $(n=148)$ from a dairy herd where the disease eradication has been carrying out since 2002 . The herd is located in Santa Rita, Arequipa, Perú, and samples were collected twice on a 30-day interval. Antibodies against BVDV and BVDV antigen were analyzed by viral neutralization and capture ELISA tests respectively. Neutralising antibodies against BVDV were detected in $6.8 \%(10 / 148)$ of animals, and most reactors were 19 to 23 months of age. The antibody titer ranged from 8 to $>256$. None persistently infected (PI) animals were found. The incidence of infection and seroconversion in the second set of samples was nill. These results suggested that the antibodies against the BVD corresponded to residual antibodies from previous infections. In addition, the results indicate the BVD infection has been controlled.

Key words: bovine viral diarrhea virus, BVDV, antibody, antigen, viral neutralization, capture ELISA, control

\section{Resumen}

Anticuerpos contra el virus de la diarrea viral bovina (VDVB) y antígeno del VDVB fueron evaluados en muestras de suero obtenidos en dos oportunidades, con intervalo de 30 días, en animales de 10 a 23 meses de edad $(n=148)$ de un establo de bovinos productores de leche que se encuentra en proceso de erradicación de la enfermedad de la diarrea viral bovina (DVB) desde 2002 . El establo está localizado en Santa Rita, Arequipa. Los anticuerpos y el antígeno viral se analizaron mediante las pruebas de neutralización viral y ELISA de captura, respectivamente. El 6.8\% (10/148) de los animales presentaron anticuerpos contra el VDVB, existiendo un mayor número de animales con anticuerpos en el grupo etario de 19 a 23 meses de edad. Los títulos de anticuerpos variaron entre 8 a $>256$. No se detectaron animales portadores (PI) ni se encontró seroconversión en el segundo muestreo, lo que sugiere que los anticuerpos detectados correspondieron a

\footnotetext{
${ }^{1}$ Práctica privada.

${ }^{2}$ Laboratorio de Microbiología y Parasitología Veterinaria, FMV-UNMSM

${ }^{3}$ E-mail: hriverag2005@yahoo.es
} 
infecciones pasadas; además, los resultados indican que la enfermedad de la DVB ha sido controlada en el hato.

Palabras clave: diarrea viral bovina, DVB, anticuerpo, antígeno, neutralización viral, ELISA, control

\section{INTRODUCCIÓN}

La diarrea viral bovina (DVB) es una enfermedad de distribución mundial y tiende a ser endémica en la mayoría de las poblaciones bovinas, alcanzando prevalencias de 60 a 80\% (Houe, 1995; Taylor et al., 1997). La enfermedad ocasiona pérdidas económicas en la industria lechera, ya que el animal infectado puede disminuir la producción de leche, así como presentar fallas reproductivas, desórdenes respiratorios o digestivos, y retardo en el crecimiento, entre otros (Houe, 2003).

La enfermedad es producida por el virus de la diarrea viral bovina (VDVB), un miembro del género pestivirus, familia Flaviviridae, que afecta principalmente a los rumiantes domésticos y silvestres (Ridpath, 2003). El virus afecta todos los tejidos, incluyendo la placenta del animal gestante. La infección fetal, durante el primer tercio de la gestación, puede resultar en el nacimiento de animales persistentemente infectados (PI) o portadores del virus, los cuales son la principal fuente de transmisión viral (Houe, 1995).

La enfermedad de la DVB fue introducida al país en la década del 60 con la importación de vacas de países donde la enfermedad era endémica (Rivera, 1993). Posteriores estudios epidemiológicos demuestran que la DVB está ampliamente difundida en la población bovina, especialmente en las principales cuencas lecheras como Cajamarca, Lima y Arequipa, ocasionando abortos (Rivera, 2001) y afecciones respiratorias como parte del complejo respiratorio bovino (Rivera et al., 1994; Zanabria et al., 2000). La DVB no es restrictiva para el tránsito de los animales a nivel nacional, lo cual explica su amplia difusión, no solo en la población bovina, sino también en otras especies como los camélidos sudamericanos (A lvarez et al., 2002). Así mismo, se han detectado PIs o animales portadores del virus (Morales $e t$ al., 2003; Rivera et al., 2003). El conocimiento del rol de los animales PI en la transmisión del VDVB ha sido la base para la erradicación de la enfermedad en algunos países europeos como Dinamarca y Suecia (Sandvik, 2004).

La cuenca lechera de Arequipa, constituida principalmente por las irrigaciones de Majes, La Joya y Santa Rita, es una de las más importantes del país por su aporte a la producción láctea nacional y por sus posibilidades de mayor desarrollo. Arequipa, con una población aproximada de 66,200 bovinos (11.7\% del total nacional) cuenta con una producción de leche de 477,000 1/día, siendo la irrigación de Santa Rita una de las más importantes zonas ganaderas, con alrededor de 25 establos y un promedio de producción de leche de 17 1/día (Olivera, 2001). Algunos de los ganaderos cuentan con 100 a 300 vacas en producción, criadas de modo intensivo, y como es usual en este tipo de crianza, afrontan serios problemas de tipo reproductivo.

En el 2002 se identificó un hato con 300 vacas en producción donde los abortos superaban el 20\% anual (Jayashi et al., 2005). El VDVB fue uno de los agentes asociados al aborto, por lo que se inició un programa de control. Se muestreó a todos los animales mayores a 6 meses del hato, determinándose una prevalencia de $98.3 \%$ (590/600) e identificándose varios animales PI. En el 2003, los muestreos se realizaron en animales de 6 a 24 meses, eliminándose los PI, reduciéndose 
la prevalencia del VDVB de 80.3 a $22.8 \%$ (Jayashi et al., 2005). Desde que se implementa un programa de control de DVB en un hato lechero hasta que se le considere libre de la enfermedad, existe un periodo de riesgo de infección por el VDVB si en el hato hubieran quedado animales PI o si se introduce animales infectados transitoriamente. Este periodo de riesgo es de dos años considerando que el animal PI de mayor edad tuvo 6 meses en esa época (Grooms, 2004).

En el presente estudio se evaluó a los animales de un hato lechero que se encuentra bajo un programa de control-erradicación de la DVB, con el fin de detectar anticuerpos contra el VDVB en animales de 10 a 23 meses de edad como un mecanismo de evaluación del programa.

\section{Materiales y Métodos}

\section{Toma de muestras}

En abril del 2005 se colectó sangre de los animales de un hato lechero de la irrigación Santa Rita en Arequipa, el cual estaba bajo un programa de erradicación de DVD. Se muestrearon todos los animales que tenían entre 10 y 23 meses de edad $(n=148)$ mediante punción de la arteria coccígea media con agujas $\mathrm{N}^{\mathrm{o}} 20$ y tubos al vacío estériles. Las muestras se llevaron al Laboratorio de Virología de la Facultad de Medicina Veterinaria (FMV) de la Universidad Nacional Mayor de San Marcos (UNMSM) para la obtención del suero, los cuales fueron guardados en viales estériles a $-20{ }^{\circ} \mathrm{C}$ hasta el momento de la prueba. El muestreo se repitió a los 30 días con el fin de observar la incidencia del virus.

\section{Detección de anticuerpos y antígenos}

Se detectaron anticuerpos contra el VDVB mediante la prueba de neutralización viral, según el protocolo disponible en el Laboratorio de Virología de la FMV de la UNMSM.
El antígeno viral fue detectado mediante la prueba de ELISA de captura de procedencia comercial (SVANOVA Biotech, Suecia) según el protocolo del kit.

Se emplearon células de cornete nasal de feto bovino libres del VDVB como sistema indicador, medios de cultivo celular Leibovitz (L-15,) e Eagle Minimal Essencial Medium (MEM) en proporción 50:50 suplementados con $10 \%$ de suero fetal bovino libres del VDVB, y antibióticos comerciales (Sigma, EEUU). Como antígeno se usó la cepa viral Singer, prototipo del biotipo $\mathrm{CP}$, genotipo I, con título de $10^{-4} \mathrm{DI}_{50} \mathrm{CC} / 50 \mu \mathrm{l}$.

\section{Análisis de datos}

Los resultados de los animales fueron agrupados según su edad al momento del muestreo: 10 a 12 meses (Grupo A), 13 a 18 meses (Grupo B), 19 a 23 meses (Grupo C). La prevalencia del VDVB en el grupo de animales del hato se calculó con un intervalo de confianza del 95\%. La prueba de Chi Cuadrado se utilizó para determinar posible asociación entre la edad (los tres grupos) y la seropositividad de los animales usando un nivel de significancia del $5 \%$.

\section{Resultados}

La presencia de anticuerpos contra el VDVB en el primer muestreo fue de $8.1 \pm$ $4.4 \%(12 / 148)$ y de $6.8 \pm 4.1 \%$ en el segundo muestreo. No se encontró asociación entre los grupos etarios y la seropositividad con la prueba de Chi Cuadrado, aunque pudo observarse un $10.6 \%$ de animales seropositivos en el grupo $\mathrm{C}$.

Los títulos de anticuerpos estuvieron en un rango de 2 a $>256$. Los títulos altos (128 a $>256$ ) se presentaron mayormente en el grupo C, mientras que los títulos bajos (2-8) desaparecieron en el segundo muestreo (Cuadro 3). 
Cuadro 1. Bovinos con anticuerpos contra el virus de la diarrea viral bovina (VDVB) en dos muestreos consecutivos, con un intervalo de 30 días, en animales de 10 a 23 meses de edad de un hato lechero en Santa Rita, Arequipa (2005)

\begin{tabular}{|c|c|c|c|c|c|}
\hline \multirow[b]{2}{*}{ Muestreo } & \multirow{2}{*}{$\begin{array}{c}\text { Animales } \\
\text { (n) }\end{array}$} & \multirow{2}{*}{$\begin{array}{c}\text { Animales } \\
\text { seropositivos } \\
\text { (n) }\end{array}$} & \multirow{2}{*}{$\begin{array}{c}\text { Prevalencia } \\
(\%)\end{array}$} & \multicolumn{2}{|c|}{ Intervalo de confianza } \\
\hline & & & & $\begin{array}{l}\text { Límite } \\
\text { superior }\end{array}$ & $\begin{array}{l}\text { Límite } \\
\text { inferior }\end{array}$ \\
\hline $1^{\mathrm{er}}$ & 148 & 12 & 8.1 & 12.5 & 3.7 \\
\hline $2^{\text {do }}$ & 148 & 10 & 6.8 & 10.9 & 2.7 \\
\hline
\end{tabular}

Cuadro 2. Bovinos con anticuerpos contra el virus de la diarrea viral bovina (VDVB) en dos muestreos consecutivos, con un intervalo de 30 días, de un hato lechero en Santa Rita, Arequipa, según el grupo etario (2005)

\begin{tabular}{lccccccccc}
\hline & \multicolumn{1}{c}{ Grupo etario } \\
\cline { 2 - 9 } & \multicolumn{2}{c}{$10-12$ meses } & $13-18$ meses & $19-23$ meses & \multicolumn{2}{c}{ Total } \\
\cline { 2 - 9 } & $\mathrm{a}$ & $\mathrm{b}$ & $\mathrm{a}$ & $\mathrm{b}$ & $\mathrm{a}$ & $\mathrm{b}$ & $\mathrm{a}$ & $\mathrm{b}$ \\
\hline Animales (n) & 14 & 14 & 49 & 49 & 85 & 85 & 148 & 148 \\
Seropositivos (n) & 1 & 0 & 2 & 1 & 9 & 9 & 12 & 10 \\
\hline Reactores (\%) & 7.1 & 0 & & 4.1 & & 10.6 & 8.1 & 6.8 \\
\hline
\end{tabular}

a:Primer muestreo

b:Segundo muestreo

Cuadro 3. Títulos de anticuerpos contra el virus de la diarrea viral bovina (VDVB) en bovinos de un hato lechero de la irrigación Santa Rita, Arequipa, en dos muestreos consecutivos, con un intervalo de 30 días, según el grupo etario (2005)

\begin{tabular}{cccccc}
\hline \multirow{2}{*}{$\begin{array}{c}\text { Edad } \\
(\text { meses })\end{array}$} & $\begin{array}{c}\text { Animales } \\
(\mathrm{n})\end{array}$ & Muestreos & \multicolumn{3}{c}{ Títulos de anticuerpos contra el VDVB ${ }^{1}$} \\
\cline { 4 - 6 } $10-12$ & 14 & $\mathrm{a}$ & $8-16$ & $32-64$ & $128->256$ \\
\hline \multirow{2}{*}{$13-18$} & 49 & $\mathrm{~b}$ & 0 & 0 & 0 \\
& & $\mathrm{a}$ & 1 & 0 & 0 \\
$19-23$ & $\mathrm{~b}$ & 0 & 0 & 1 \\
& 85 & $\mathrm{a}$ & 0 & 0 & 9 \\
\hline
\end{tabular}

1 Inversa de la dilución

a:Primer muestreo

$\mathrm{b}$ :Segundo muestreo 
No se encontraron animales PI. Tampoco se observó seroconversión de anticuerpos ni incidencia del VDVB a los 30 días del primer análisis.

\section{Discusión}

La presencia de un grupo de hembras entre 10 a 23 meses de edad que habrían estado en contacto con PI detectados en enero del 2004 motivó el presente estudio. La frecuencia de animales que presentaron anticuerpos contra el VDVB fue baja ( $8.1 \mathrm{y}$ $6.8 \%$ en cada uno de los muestreos), no se detectaron animales PI adicionales, ni hubo seroconversión. Este resultado indica ausencia de la infección en el hato y demuestra que la enfermedad de la DVB está siendo controlada a través de la utilización del programa de control impuesto sin uso de vacuna contra DVB (Cuadro1).

El mayor número de animales seropositivos se encontró en el grupo de animales entre 19 a 23 meses de edad y un menor número, entre 10 a 18 meses de edad (Cuadro 2). Los anticuerpos detectados en estos animales probablemente fueron inducidos por el VDVB que estuvo circulando en el hato antes o durante la eliminación de los animales PI y cuando varias de las terneras tuvieron cerca de 8 meses de edad. Los anticuerpos de origen materno no se pueden detectar pasados los 6 meses de edad con la prueba de neutralización viral, de allí que si no hay desafío, permanecen seronegativos y susceptibles a la infección por el VDVB; si el animal se infecta durante este tiempo puede presentar una infección aguda con discretos signos clínicos pero desarrollan una sólida respuesta inmunitaria por anticuerpos neutralizantes en una a tres semanas post infección, incrementándose los niveles de anticuerpos en 10 a 12 semanas post infección, hasta alcanzar la meseta permaneciendo en niveles altos por varios años (Fredriksen et al., 1999).
Los títulos de los anticuerpos detectados en estos animales fluctuaron entre 2 a $>256$ (Cuadro 3). Estos anticuerpos podrían corresponder a la meseta, es decir, al tiempo durante el cual los anticuerpos permanecen elevados hasta eventualmente declinar en forma lenta (Fredriksen et al., 1999). Los títulos de anticuerpos neutralizantes pueden variar en los rangos arriba indicados, dependiendo de factores como grado y tiempo de exposición o desafío, capacidad de respuesta del animal, etc. Un segundo análisis serólogico efectuado a los mismos animales 30 días posterior a la primera toma de la muestra indicaron que la incidencia de la DVB fue cero y los títulos mayores a 64 permanecieron constantes, mientras que los que tuvieron entre 2 a 8 no fueron detectados (H. Rivera, comunicación personal). Este hallazgo evidencia que los anticuerpos detectados fueron inducidos por infecciones pasadas, ya que no hubo seroconversión en el resto de animales indicando la ausencia de desafío viral. Los bajos títulos de anticuerpos (2-8) detectados en el primer muestreo pudieron haber sido errores de lectura, neutralizaciones inespecíficas, o que estos anticuerpos estaban por desaparecer.

Usualmente un animal PI es capaz de infectar a $90 \%$ ó más de los animales susceptibles del hato (Houe, 1992; Schreiber et al., 1999); por tanto, si hubiera existido virus de campo en este grupo de animales habría infectado rápidamente a la mayoría de las vaquillas, ya que estaban sin anticuerpos contra el VDVB. No se encontró asociación entre los grupos etarios A, B y C con la seropositividad al VDVB mediante el análisis de Chi Cuadrado. La ausencia de virus de campo en el hato indica que el programa de control implementado bajo los criterios utilizados en países como Suecia, (Sandvick, 2004) está dando buenos resultados y podría ser tomado como un programa piloto para ser aplicado en forma voluntaria, principalmente en grandes hatos de crianza intensiva y que manejen un buen sistema de bioseguridad. 
Los conocimientos de la patogénesis y biología de este agente viral ha permitido un enfoque diferente, donde la identificación y eliminación de los animales PI es la base para el control (Sandvik, 2004). La situación de la DVB en EE.UU. es una evidencia de que la vacunación por sí sola no es una medida adecuada. Las vacunas contra DVB son buenos inmunógenos pero su aplicación debe restringirse a los animales donde las condiciones zoosanitarias lo ameriten. El impacto económico y las exitosas experiencias de algunos países europeos en la erradicación de la enfermedad están motivando a la comunidad veterinaria y ganaderos, inclusive de EE.UU., para implementar medidas de control y erradicación de la DVB basados principalmente en la detección y eliminación de los animales PI (Fulton et al., 2003).

Los problemas sanitarios endémicos antes de la implementación del programa de control de la DVB en el hato en estudio estaban referidos a un $20 \%$ de abortos al año y frecuentes problemas neumoentéricos en los terneros. Según los registros del establo, el porcentaje de abortos no ha disminuido, posiblemente debido a la presencia de la neosporosis, que es considerada como uno de los principales agentes abortogénicos en bovinos en el mundo. Diversos estudios señalan que un 10 a $17.3 \%$ de abortos al año son debido a este parásito (Thurmond et al., 1997; Anderson et al., 2000). Sin embargo, en estos dos últimos años (2004-2005) los problemas respiratorios y entéricos en los terneros casi han desaparecido sugiriendo que el VDVB habría sido un factor en su presentación por su efecto inmunodepresor y predisponente a infecciones secundarias, sobre todo en animales jóvenes. No obstante, la observación de las medidas de bioseguridad podría estar contribuyendo a la mejora sanitaria y al éxito del programa de control de la DVB en el hato en estudio.

\section{Conclusiones}

- El $6.8 \pm 4.1 \%$ de los animales tenían anticuerpos contra el VDVB después de 3 años de la aplicación del programa de control en el establo y 2 años después de la eliminación de los últimos animales PI.

- No se encontró asociación estadísticamente significativa entre la edad de los animales y la presencia de anticuerpos contra el VDVB.

- No se encontró animales PI con el VDVB en el hato.

\section{Agradecimientos}

Los autores agradecen la colaboración y apoyo brindado por el Dr. Augusto Zelada y el propietario del establo, Ing. D. Lozada. Así mismo, agradecen a la Dra. Nieves Sandoval por sus acertados comentarios sobre el trabajo.

\section{Literatura Citada}

1. Alvarez, S.; H. Rivera; D. Pezo; W. García. 2002. Detección de anticuerpos contra pestivirus en rumiantes de una comunidad campesina de la provincia de Canchis, Cusco. Rev. Inv. Vet., Perú 13: 46-51.

2. Anderson, M.; A. Andrianarivo; P. Conrad. 2000. Neosporosis in cattle. Anim. Reprod. Sci. 60: 417-431.

3. Fredriksen, B.; T. Sandvik; T. Loken; S. Odegaard. 1999. Level and duration of serum antibodies in the cattle infected experimentally and naturally with bovine virus diarrhea virus. Vet. Rec. 144: 111-114.

4. Fulton, R.; J. Ridpath; A. Confer; J. Saliki; L. Burge; M. Payton. 2003. Bovine viral diarrhea virus antigenic diversity: impact on disease and vaccination programmes. Biologicals 31 : 89-95. 
5. Grooms, D.L. 2004. Reproductive consequence of infection with bovine virus diarrhea virus. Vet. Clin. Food Anim. 20: 5-19.

6. Houe, H. 1992. Serological analysis of a small herd sample to predict presence or absence of animals persistently infected with bovine viral diarrhoea virus (BVDV) in dairy herds. Res. Vet. Sci. 53: 320-323.

7. Houe, H. 1995. Epidemiology of bovine viral diarrhea virus. Vet. Clin. North Am. Food Anim. Practice 11: 521-547.

8. Houe, H. 2003. Economic impact of BVDV infection in dairies. Biologicals 31: 137-143.

9. Jayashi, C.; C. Gavidia; M. Araínga; A. Manchego; H. Rivera. 2005. Dinámica de seroconversión en hembras bovinas post eliminación de animales portadores del virus de la diarrea viral bovina. Rev. Inv. Vet., Perú 16: 56-64.

10. Morales, S.; A. Benito; H. Rivera. 2002. Terneros persistentemente infectados con el virus de la diarrea viral bovina en dos hatos lecheros de la provincia de Arequipa. Rev. Acad. Peru. Cienc. Vet. 3: 8-13.

11. Olivera, L. 2001. Sanidad del ganado lechero de la cuenca del sur. Rev. Inv. Vet., Perú 12: 78-86.

12. Ridpath, J. 2003. BVDV genotypes and biotypes: practical implications for diagnosis and control. Biologicals 31: 127-131.

13. Rivera, H. 1993. El virus de la diarrea viral bovina (DVB). Rev. Inv. Pec. IVITA (Perú) 6: 1-6.

14. Rivera, H. 2001. Etiología infecciosa del aborto bovino. Rev. Inv. Vet., Perú. Supl. 1: 95-99.
15. Rivera, H.; A. Manchego; N. Sandoval; C. Morales; E. Flores. 1994. Complejo respiratorio bovino en terneros del valle de Lima. Rev. Inv. Pec. IVITA (Perú) 7: 35-38.

16. Rivera, H.; K. Huamán; A. Benito; A. Díaz; C. Arana. 2003. Prevalencia del virus de la diarrea viral bovina y animales portadores del virus en un hato lechero del valle del Mantaro. Rev. Acad. Peru. Cienc. Vet. 3: 1-7.

17. Sandvik, T. 2004. Progress of the control and prevention programs for bovine viral diarrhea virus in Europe. Vet. Clin. Food Anim. 20: 151-169.

18. Schreiber, P.; F. Dubois; F. Dreze; N. Lacroix; B. Limbourg; Ph. Coppe. 1999. Prevalence of bovine virus diarrhea virus in Belgian White Blue cattle in southern Belgium. Vet. Quart. 21: 28-32.

19. Taylor, L.; D. Janzen; J. Ellis; J. van den Hurk; P. Ward. 1997. Performance, survival, necropsy, and virological findings from calves persistently infected with bovine viral diarrhea virus originating from a single Saskatchewan beef herd. Can. Vet. J. 38: 29-37.

20. Thurmond, M.; D. Hietala; P. Blanchard. 1997. Herd-based diagnosis of Neospora caninum-induced endemic and epidemic abortion in cows and evidence for congenital and postnatal transmission. J. Vet. Diagn. Invest. 9: 44-49.

21. Zanabria, V.; H. Rivera; R. Rosadio. 2000. Etiología del síndrome neumónico agudo en vacunos de engorde en Lima. Rev. Inv. Vet., Perú. 11: 169-187. 